\title{
Changes in illite crystallinity within an ancient tectonic boundary thrust caused by thermal, mechanical, and hydrothermal effects: an example from the Nobeoka Thrust, southwest Japan
}

Rina Fukuchi ${ }^{1,4^{*}}$, Koichiro Fujimoto ${ }^{2}$, Jun Kameda ${ }^{3}$, Mari Hamahashi ${ }^{1}$, Asuka Yamaguchi ${ }^{4}$, Gaku Kimura ${ }^{1}$, Yohei Hamada ${ }^{5}$, Yoshitaka Hashimoto ${ }^{6}$, Yujin Kitamura ${ }^{7}$ and Saneatsu Saito ${ }^{5}$

\begin{abstract}
Illite crystallinity (IC), the full width at half maximum of the illite (001) peak in clay-fraction X-ray diffraction (XRD), is a common geothermometer widely applied to various tectonic settings. Paleotemperature estimation using IC presents methodological ambiguity because $\mathrm{IC}$ is not only affected by background temperature but also by mechanical, hydrothermal, and surface weathering effects. To clarify the influences of these effects on IC in the fault zone, we analyzed the IC and the illite 001 peak intensity of continuous borehole core samples from the Nobeoka Thrust, a fossilized tectonic boundary thrust in the Shimanto Belt, the Cretaceous-Paleogene Shimanto accretionary complex in southwest Japan. We also carried out grinding experiments on borehole core samples and sericite standard samples as starting materials and investigated the effect of mechanical comminution on the IC and illite peak intensity of the experimental products. We observed the following: (1) the paleotemperatures of the hanging wall and footwall of the Nobeoka Thrust are estimated to be $288^{\circ} \mathrm{C}$ to $299^{\circ} \mathrm{C}$ and $198^{\circ} \mathrm{C}$ to $249^{\circ} \mathrm{C}$, respectively, which are approximately $20^{\circ} \mathrm{C}$ to $30^{\circ} \mathrm{C}$ lower than their previously reported temperatures estimated by vitrinite reflectance; (2) the fault core of the Nobeoka Thrust does not exhibit IC decrease; (3) the correlation of IC and illite peak intensity in the hanging wall damage zone were well reproduced by the grinding experiment, suggesting that the effect of mechanical comminution increases toward the fault core and; (4) the abrupt increase in IC value accompanied by high illite peak intensity is explained by hydrothermal alterations including plagioclase breakdown and the formation of white micas. Our results indicate that IC has potential for quantifying the effects of mechanical comminution and hydrothermal alteration within a fault zone.
\end{abstract}

Keywords: Illite crystallinity; Nobeoka thrust; X-ray diffraction; Comminution; Hydrothermal alteration; Tectonic boundary thrust

\footnotetext{
* Correspondence: rfukuchi@aori.u-tokyo.ac.jp

${ }^{1}$ Department of Earth and Planetary Science, Graduate School of Science,

The University of Tokyo, 7-3-1 Hongo, Bunkyo-ku, Tokyo 113-0033, Japan

${ }^{4}$ Atmosphere and Ocean Research Institute, The University of Tokyo, 5-1-5,

Kashiwanoha, Kashiwa-shi, Chiba 277-8564, Japan

Full list of author information is available at the end of the article
} 


\section{Background}

Rapid slip on a plate boundary megathrust or megasplay fault branching from the plate boundary causes large earthquakes and tsunamis in the subduction zone. The seismogenic depth of the subduction zone might be thermally controlled: the temperature of the updip limit of the seismogenic zone is approximately $120^{\circ} \mathrm{C}$ to $150^{\circ} \mathrm{C}$, while that of the downdip limit is approximately $350^{\circ} \mathrm{C}$ to $450^{\circ} \mathrm{C}$ (Hyndman and Wang 1993, 1995; Hyndman et al. 1997; Oleskevich et al. 1999). Direct observation of modern seismogenic subduction zones is rather difficult, and thus exhumed accretionary complexes provide an invaluable opportunity to study the nature of faulting at seismogenic depths.

The Nobeoka Thrust in Japan, a large-scale tectonic boundary thrust in the Shimanto accretionary complex, is considered a fossilized seismogenic megasplay fault based on its paleotemperatures $\left(250^{\circ} \mathrm{C}\right.$ to $320^{\circ} \mathrm{C}$ ) (Kondo et al. 2005) and on the discovery of pseudotachylyte in its hanging wall damage zone (Okamoto et al. 2006). The elucidation of the fault mechanics of the Nobeoka Thrust would therefore provide key information for our understanding of subduction zone earthquakes.

Illite crystallinity (IC) is a common geothermometer (Kübler 1968) that has been widely applied to various tectonic settings including the Shimanto accretionary complex in Japan (Underwood et al. 1993; Awan and Kimura 1996; Hara and Kimura 2000; Mukoyoshi et al. 2007). However, the estimation of paleotemperature from IC values may be problematic because IC can also be affected by other factors such as lithology, deformation, hydrothermal alteration, and surface weathering (Hara and Kimura 2000). Hara and Kimura (2000) in particular emphasized that these factors readily influence the IC values near a fault zone, and thus that IC value does not necessarily reflect background paleotemperature. However, if such factors are appropriately isolated, the IC of the fault zone has potential for assessing thermal, mechanical, and hydrothermal effects related to faulting.

To identify the factors controlling the IC value within the fault zone, we analyzed continuous borehole core samples of the Nobeoka Thrust using a powder X-ray diffraction (XRD) analysis. We also carried out grinding experiments using a planetary ball mill and investigated the changes in the IC of the experimental products. Based on the results, we discuss the effects controlling the IC within a fault zone located in the subduction zone.

\section{Geological setting and borehole core lithology Geological setting}

The Nobeoka Thrust is a large thrust bounding the northern and southern Shimanto Belt, the CretaceousPaleogene accretionary complex in Kyushu, Southwest Japan (Kimura 1998; Murata 1998; Kondo et al. 2005;
Figure 1a,b). The Nobeoka Thrust presents the largest lithological and paleothermal gaps in the Shimanto Belt in Kyushu and is traced for approximately $100 \mathrm{~km}$. The thrust is well exposed along the rocky coastline near Nobeoka City (Figure 1c). The hanging wall of the thrust is the Eocene Kitagawa group, composed of phyllitic

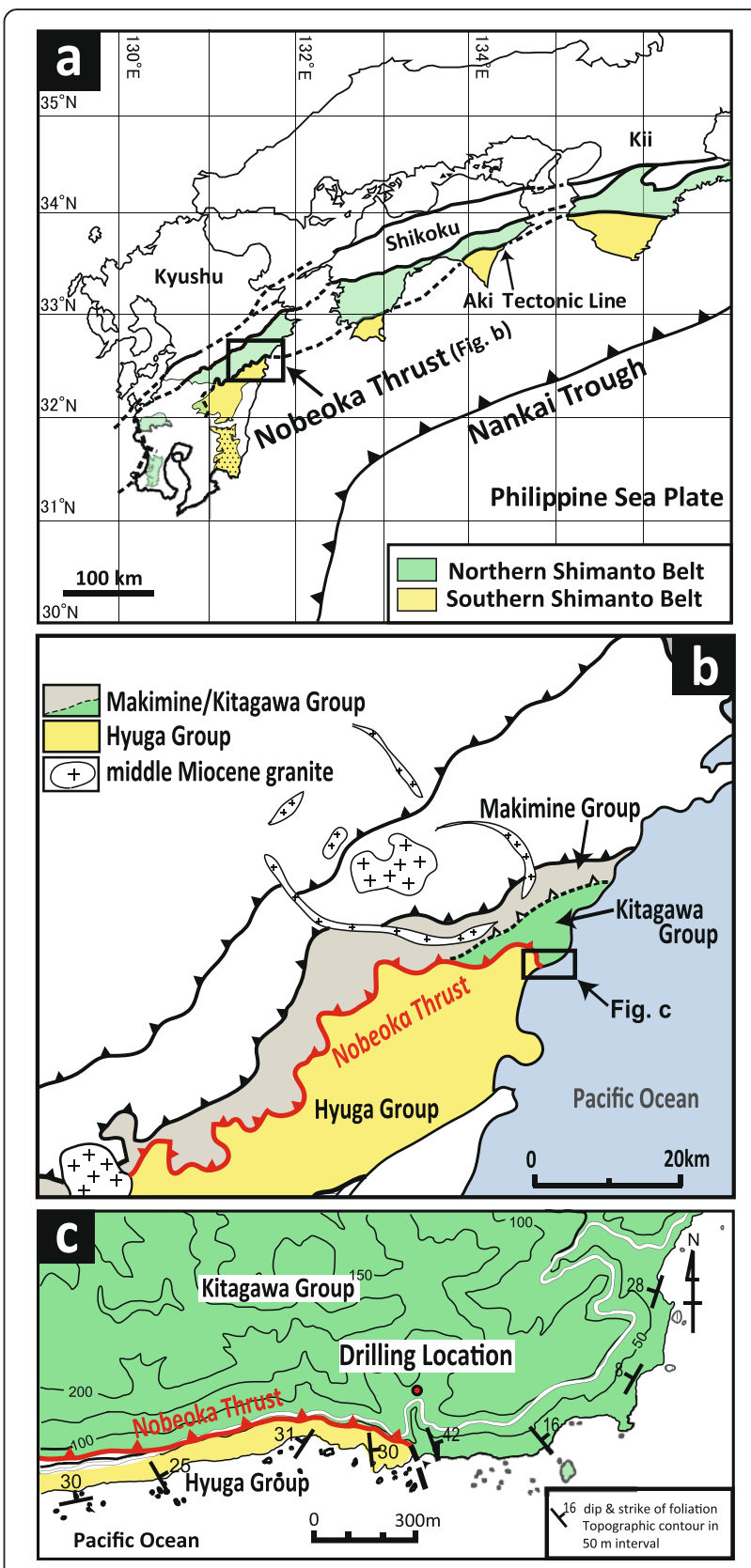

Figure 1 Geologic setting of the Nobeoka Thrust. (a) Geologic setting of the Nobeoka Thrust and distribution of the Shimanto Belt in Southwest Japan. (b) A simplified geologic map of the Shimanto Belt in northeast Kyushu, modified from Murata (1998). (c) Geologic map of the studied area and the locality of the drilling site (dot) for the hanging wall of the Nobeoka Thrust (modified from Kondo et al. 2005; Kimura et al. 2013; Hamahashi et al. 2013). 
shales and sandstones (Okumura et al. 1985; Kondo et al. 2005), whereas the footwall is the Hyuga group, consisting of a cataclastic mélange of shale matrix with sandstone and basaltic blocks (Nishi 1988; Kimura et al. 1991; Kondo et al. 2005). Microfossil assemblages indicate the depositional age to be from middle Eocene to early Oligocene (Saito et al. 1996). The paleotemperatures of the hanging wall and footwall based on vitrinite reflectance analysis are estimated to be approximately $320^{\circ} \mathrm{C}$ and $250^{\circ} \mathrm{C}$, respectively (Kondo et al. 2005).

The $70^{\circ} \mathrm{C}$ temperature difference between the hanging wall and footwall is explained by the displacement of approximately 8.6 to $14.4 \mathrm{~km}$ along the thrust under a depth of up to $11 \mathrm{~km}$ beneath the seafloor (Kondo et al. 2005; Hara and Kimura 2008; Raimbourg et al. 2009). Such a displacement is comparable to that of the deep portion of the modern megasplay fault in the Nankai Trough (Kondo et al. 2005; Hamahashi et al. 2013). Several detailed structural investigations focused on good surface exposure have been performed (Kondo et al. 2005; Okamoto et al. 2006; Yamaguchi et al. 2011; Kimura et al. 2013).

\section{Borehole core lithology}

The Nobeoka Thrust Drilling Project (NOBELL) was conducted (see Figure 1c for the drill sites) to investigate the mechanics and evolution of the fossilized tectonic boundary thrust. Coring and geophysical logging operations were performed from July to September 2011. Continuous core samples down to $255 \mathrm{~m}$ below the ground surface (hereafter referred as 'mbgs') were retrieved at the excellent recovery rate of $99.82 \%$ (Figure 2), and valuable datasets of geophysical logging were also collected.

The fault core (at the principal slip zone) of the Nobeoka Thrust was obtained at a depth of 41.3 to 41.8 mbgs. The fault core is composed of random, non-foliated cataclasite including angular to subangular clasts of sandstones, shales, and quartz veins (Hamahashi et al. 2013) (Figure 2d). Phyllites of alternating beds of sandstone and shale make up the hanging wall Kitagawa group (0 to 41.3 mbgs) (Figure 2a). Deformation structures such as phyllitic cleavages, kink folds of alternating beds of sandstones and shales, and quartz-carbonate veins characterize the hanging wall. A brittle damage zone of abundant boudinaged blocks of sandstone can be observed (Figure 2b,c), and broken phyllite containing pseudotachylyte is also present in the lowest part of the hanging wall (38.8 to 41.3 mbgs). The footwall Hyuga group (41.3 to 255 mbgs) is composed of scaly shale, tuffaceous shale, sandstone, and acidic tuff. All of these are strongly deformed to display cataclasites derived from mélange with abundant faults, fractures, and mineral veins on the core surfaces. The footwall is divided into four lithologic units (Figures 3 and 4) based on the abundance of sandstone and tuff. Random fabric cataclasites are dominant in unit 1, whereas units 2 to 4 are dominated by foliated cataclasites. A fault zone with fine-grained breccias comprises the boundary between units 3 and 4.

\section{Experimental procedure}

We conducted grinding experiments using a planetary ball mill housed at the Tokyo Gakugei University (FRITSCH P-6). A borehole core sample selected from $35.49 \mathrm{mbgs}$ was used as the starting material of the grinding experiment. The sample had a relatively small IC value $(0.27$ $\left.\left(\Delta^{\circ} 2 \theta\right), 35.49 \mathrm{mbgs}\right)$ and high peak intensity $(638 \mathrm{cps}, 35.49$ mbgs) and was therefore expected to be appropriate as the starting material to trace IC changes during the experiment. We also conducted grinding experiments with a sericite standard sample (JCSS-5102; The Clay Science Society of Japan [Miyawaki et al. 2010]) as the starting material, as it a

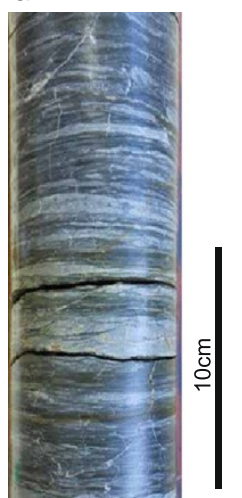

b

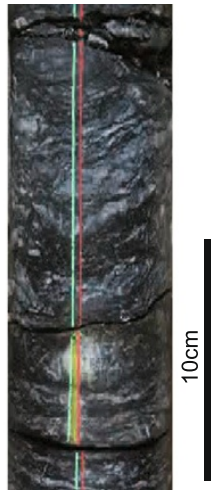

C

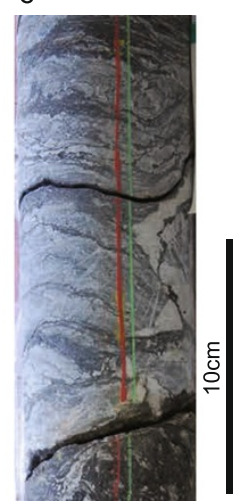

d

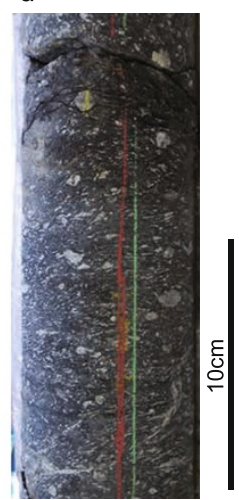

Figure 2 Borehole core photos showing deformational features $20 \mathrm{~cm}$ each of the hanging wall of the Nobeoka Thrust. Note that the photos are outward appearance of cores before splitting, and inclined planar structures such as faults and fractures are not represented as a straight line. (a) Phyllite with minor brittle deformation, 3.50 to $3.70 \mathrm{mbgs}$. (b) Moderately deformed brittle damage zone, 39.40 to $39.60 \mathrm{mbgs}$. (c) Highly deformed damage zone just above the fault core with quartz and calcite veins, 41.10 to $41.30 \mathrm{mbgs}$. (d) Fault core consisting of random, non-foliated cataclasite including angular to subangular clasts of sandstones, shales, and quartz veins, 41.30 to 41.50 mbgs. 


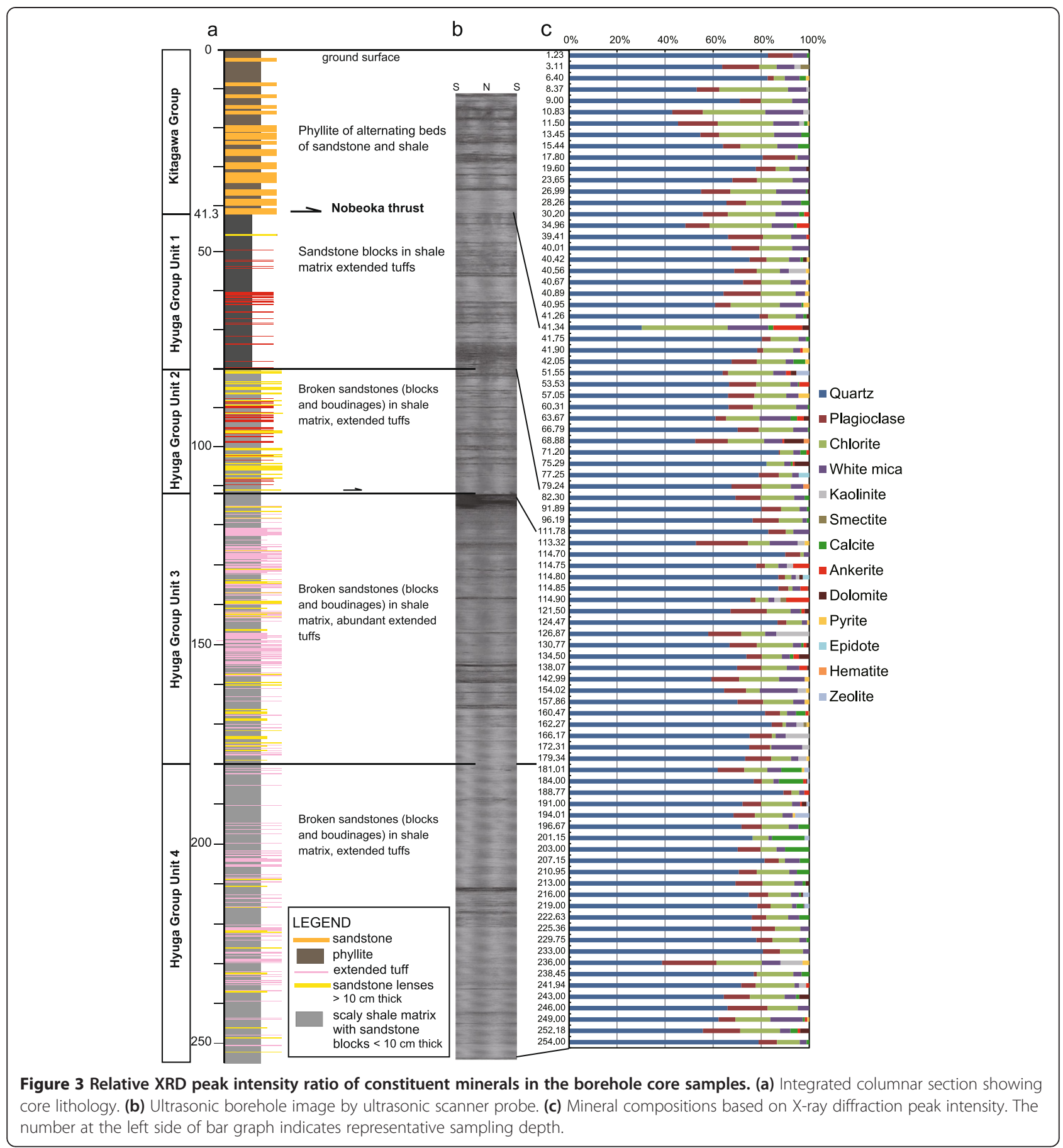

has an IC value $\left(0.21 \Delta^{\circ} 2 \theta\right)$, which is similar to that of the borehole core sample selected from 35.49 mbgs.

Dry grinding of the samples was conducted at a rotation speed of $400 \mathrm{rpm}$, with an orbital radius of $7 \mathrm{~cm}$. The grinding vessel was made of tungsten carbide with a volume of $45 \mathrm{~mL}$. We used 180 tungsten carbide balls (1.00 g each) and $6.0 \mathrm{~g}$ of sample together in the vessel. The grinding time ranged from 1 to $90 \mathrm{~min}$. After the experiments, the IC values of the experimental products were analyzed as described in the following section.

\section{Methods}

We performed clay mineral analysis focusing on the IC and illite peak intensity of the borehole core samples and experimental products, and we conducted a bulkrock mineralogical analysis of the borehole core samples. 


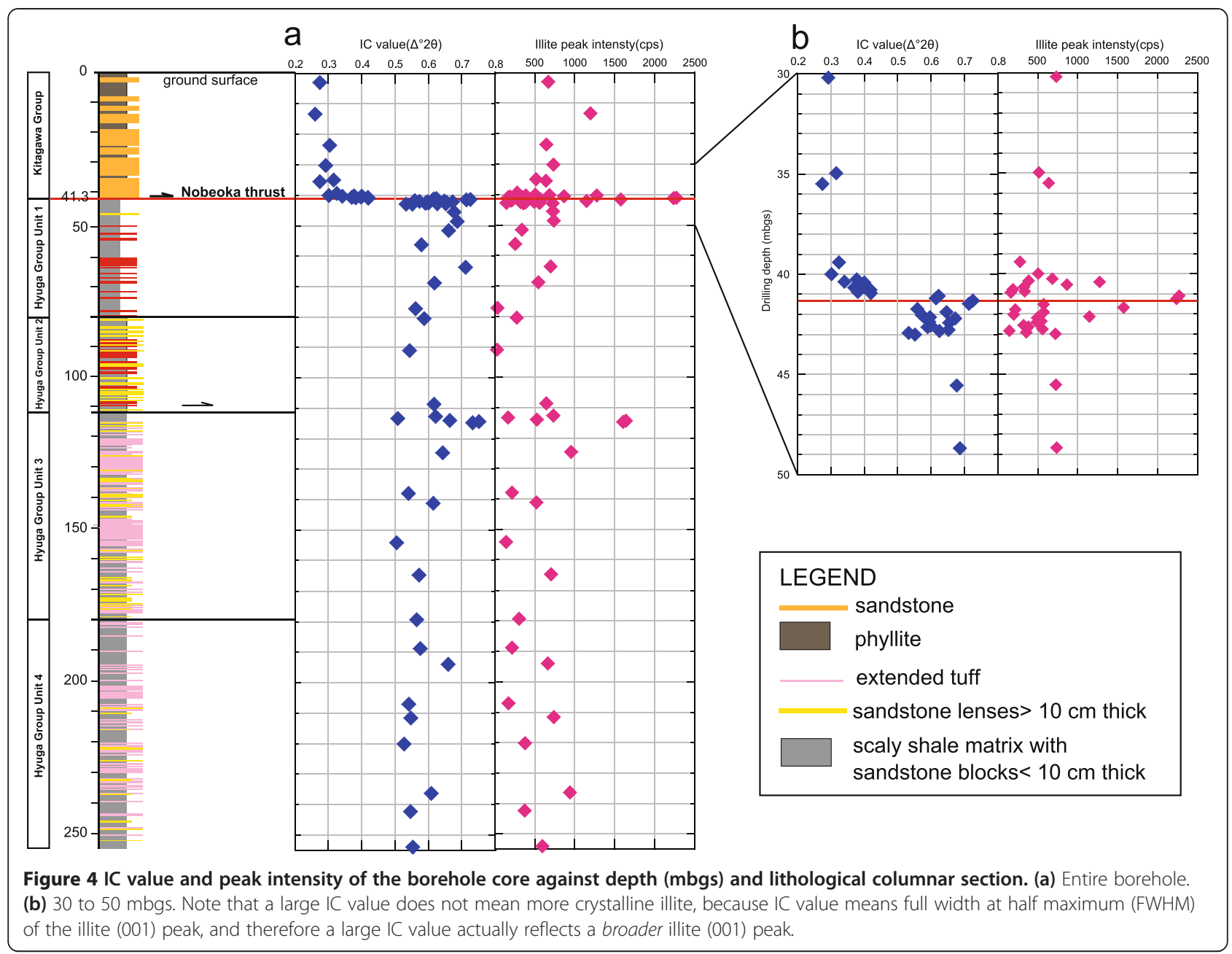

For the bulk mineral composition analysis, we selected 77 samples at approximately 3-m intervals of the borehole cores; for the clay mineral analysis, we chose 65 samples at approximately 10 -m intervals of the borehole cores, with densely sampled $(10 \mathrm{~cm})$ intervals between 40 and 42 mbgs.

We analyzed the bulk-rock mineralogy to obtain the peak intensity ratios of quartz, plagioclase, chlorite, white mica (illite), calcite, dolomite, and ankerite by the conventional powder XRD method, using the Rigaku Ultima IV X-ray diffractometer (Rigaku, Shibuya-ku, Japan) installed at Tokyo Gakugei University. The measurement conditions used for the analyses were the following: $\mathrm{CuKa}$ radiation of $40 \mathrm{kV}$ and $20 \mathrm{~mA}$, step-scan speed of $50^{\circ} 2 \theta / \mathrm{min}$, divergence and scatter slits of $1 / 2^{\circ}$, open receiving slit, and scan range of 5 to $70 \Delta^{\circ} 2 \theta$.

The sample for the clay mineral analysis was gently crushed with a pestle and mortar, and the $2-\mu \mathrm{m}$ clay size fractions were separated by gravity settling and concentrated by centrifuge before being pipetted onto glass slides to make oriented slides. The measurement conditions of the RINT 2000 X-ray diffractometer (Tokyo Gakugei University) were the following: CuKa radiation at $40 \mathrm{kV}$ and $20 \mathrm{~mA}$, step-scan speed of $0.01^{\circ} 2 \theta / \mathrm{s}$, divergence and scatter slits of $1^{\circ}$, receiving slit of $0.3 \mathrm{~mm}$, and scan range of 6.5 to $10.5 \Delta^{\circ} 2 \theta$. Samples were treated with ethylene glycol to minimize the overlapping effect of smectite peaks.

The data processing to obtain the IC value and integrated peak intensity of illite (001) was performed using Jade software (Jade Software Corp., Jacksonville, FL, USA). We examined the IC expressed as $\Delta^{\circ} 2 \theta$, which is measured as a FWHM of the illite (001) peak in clay-fraction XRD (Kübler 1968). In order to standardize the IC value, which depends on the X-ray diffractometer settings and sample preparation procedure, we measured the IC value of the Japanese Illite Crystallinity inter-laboratory standard (JIC; Hara and Kimura 2003). Measured $\Delta^{\circ} 2 \theta$ values of six JIC samples are shown in Additional file 1: Table S1. Empirical relationships between the measured IC value and JIC-calibrated IC value were obtained by collinear approximation, 


$$
\mathrm{IC}_{\text {IIC }}=1.038664 \mathrm{IC}_{\text {measured }}+0.111802
$$

The relationship between JIC and the Crystallinity Index Standard (CIS) was characterized as

$$
\mathrm{IC}_{\mathrm{CIS}}=1.55 \mathrm{IC}_{\mathrm{JIC}}-0.77 \text { (Hara and Kimura 2003) }
$$

where $\mathrm{IC}_{\text {measured }}, \mathrm{IC}_{\mathrm{JIC}}$, and $\mathrm{IC}_{\mathrm{CIS}}$ are the measured IC value, JIC-converted IC value, and CIS-converted IC value, respectively. Hereafter, we use $\mathrm{IC}_{\mathrm{JIC}}$ as 'IC' because JIC has been calibrated for the use of weakly metamorphosed accretionary prism rocks and was therefore most appropriate for application to our analyzed samples.

We examined the clay mineral grain shapes of an unground natural core sample and a natural sample ground for $10 \mathrm{~min}$ using the field emission-scanning electron microscope (FE-SEM; Hitachi S4500; Hitachi Ltd., Chiyoda-ku, Japan) installed at Tokyo Gakugei University. We observed the clay mineral grain shapes of borehole core samples from the hanging wall.

\section{Results}

The bulk-rock mineralogy analysis shows that quartz, plagioclase, illite, chlorite, and calcite are the dominant constituent minerals throughout the borehole core (Figure 3). The dominant clay minerals in the samples are white mica (illite and muscovite) and chlorite. White mica was present in every sample (Figure 3).

The results of the analysis of the IC value and illite peak against the core depth (mbgs) are shown in Table 1 and summarized in Figure 4. A marked change across the hanging wall and the footwall is visible in Figure 4. Above 38.8 mbgs, IC values and illite peak intensities in the hanging wall range from 0.26 to $0.32 \Delta^{\circ} 2 \theta$, and from 515 to 1,198 counts per second (cps), respectively; however, in the hanging wall damaged zone (38.8 to 41.0 mbgs), they increase abruptly from 0.30 to $0.62 \Delta^{\circ} 2 \theta$ and from 165 to $1,277 \mathrm{cps}$, respectively. They further increase from $0.39 \Delta^{\circ} 2 \theta$ and from 2,239 to 2,269 cps just above the fault core (41.0 to $41.3 \mathrm{mbgs}$ ). These systematic changes in IC values are shown in Figure $5 \mathrm{a}$.

The IC values and illite peak intensities of the fault core ( 41.3 to $41.8 \mathrm{mbgs}$ ) range from 0.56 to $0.73 \Delta^{\circ} 2 \theta$ and from 220 to $1,577 \mathrm{cps}$, whereas those of the footwall range from 0.51 to $0.75 \Delta^{\circ} 2 \theta$ (diagenetic zone) and 29 to $1,639 \mathrm{cps}$, respectively. IC value and peak intensity show a negative correlation within 0 to 40 mbgs: IC value increases to approximately $0.12 \Delta^{\circ} 2 \theta$ and the peak intensity decreases to approximately 1,200 to $170 \mathrm{cps}$. At 40.26 to $40.56 \mathrm{mbgs}$, intensity ranges from approximately 680 to $1,300 \mathrm{cps}$, and at 41.10 to 41.26 mbgs, the peak intensity and IC value further increase to 2,239 to $2,269 \mathrm{cps}$ and from $0.39 \Delta^{\circ} 2 \theta$, respectively.
In the footwall, a large gap in the IC value from approximately 0.5 to 0.7 is recognizable at the boundary between units 2 and 3 (Figure 4). The location of the gap coincides with a fault, and the intensities of the illite peak at $10 \AA$ (Figure 4) show patterns coincident with the changes in IC values. Remarkably high intensities of illite peaks with relatively large IC values are observed within two major fault zones: the fault core of the Nobeoka Thrust and the boundary fault between units 2 and 3 in the footwall (Figure 4 and Table 1).

Regarding the experimental products using hanging wall samples collected from 35.49 mbgs, the illite peak intensity of the samples decreases gradually with increasing grinding time, almost disappearing after 20 min of grinding and vanishing completely after $60 \mathrm{~min}$ of grinding (Figure 5b, Table 2). An approximately 0.05 to $0.10 \Delta^{\circ} 2 \theta$ increase in IC value is observed in the case of $8 \mathrm{~min}$ of grinding. The peak intensity of the experimental products using the sericite standard samples also decreases with time. The illite peak almost and completely disappears after 20 and 90 min of grinding, respectively. An approximately 0.05 to $0.10 \Delta^{\circ} 2 \theta$ increase in IC value is observed after 8 min of grinding; IC value continues to increase to $0.53 \Delta^{\circ} 2 \theta$ after $60 \mathrm{~min}$ of grinding (Table 2).

Figure 6 shows a secondary electron image (SEI) of clay mineral grain shapes of an unground natural core sample (35.49 mbgs) and a 10-min-ground natural sample. Platy euhedral hexagonal crystals of illite (approximately 1.5 to $3 \mu \mathrm{m}$ in diameter) are observable in the starting sample (Figure 6a). After $10 \mathrm{~min}$ of grinding, the platy morphology remains but the crystal shape becomes rounder and the edges are partly destroyed, a result which is associated with fine materials (Figure $6 \mathrm{~b}$ ). Figure $6 \mathrm{c}, \mathrm{d}$ shows the grain surface textures of borehole core samples collected at 3.11 and $39.41 \mathrm{mbgs}$, respectively. Textures similar to those of the ground sample are also observable in the natural sample within the damage zone (Figure 6d). In contrast, the sample from 40.95 mbgs shows very fine materials around platy crystals (Figure 6e) and that from 41.26 mbgs exhibits rather platy euhedral-like crystals (Figure 6f,g).

\section{Discussion \\ Paleotemperature}

The IC values show a clear difference between the hanging wall and footwall (Figure 4a, Table 1). Relatively homogenous IC values ranging from 0.26 to $0.32 \Delta^{\circ} 2 \theta$ above 38.8 mbgs represent the maximum diagenetic burial temperature in the hanging wall. As for the footwall, the IC values range from 0.51 to $0.75 \Delta^{\circ} 2 \theta$. The samples collected from the two major fault zones (at approximately 41 and 114 mbgs) have large IC values and high illite peak intensities, suggesting crystal formation of illite due to hydrothermal activity (see the next section). 
Table 1 IC value and illite peak intensity of all the measured samples from the entire borehole core

\begin{tabular}{|c|c|c|c|c|c|}
\hline Top (mbgs) & Bottom (mbgs) & Average (mbgs) & Illite peak intensity (CPS) & $I C_{\text {measured }}\left(\Delta^{\circ} \mathbf{2 \theta}\right)$ & $\mathrm{IC}_{\mathrm{JIC}}\left(\Delta^{\circ} \mathbf{2 \theta}\right)$ \\
\hline 3.07 & 3.14 & 3.11 & 670 & 0.16 & 0.27 \\
\hline 13.41 & 13.49 & 13.45 & 1,198 & 0.14 & 0.26 \\
\hline 23.62 & 23.67 & 23.65 & 642 & 0.19 & 0.30 \\
\hline 30.20 & 30.20 & 30.20 & 732 & 0.17 & 0.29 \\
\hline 34.92 & 35.00 & 34.96 & 515 & 0.20 & 0.32 \\
\hline 35.47 & 35.50 & 35.49 & 638 & 0.16 & 0.27 \\
\hline 39.40 & 39.42 & 39.41 & 278 & 0.21 & 0.32 \\
\hline 40.00 & 40.01 & 40.01 & 505 & 0.18 & 0.30 \\
\hline 40.36 & 40.37 & 40.37 & 390 & 0.22 & 0.34 \\
\hline 40.88 & 40.89 & 40.89 & 339 & 0.26 & 0.38 \\
\hline 40.25 & 40.26 & 40.26 & 681 & 0.26 & 0.38 \\
\hline 40.41 & 40.43 & 40.42 & 1,277 & 0.28 & 0.40 \\
\hline 40.54 & 40.57 & 40.56 & 864 & 0.28 & 0.40 \\
\hline 40.66 & 40.68 & 40.67 & 327 & 0.25 & 0.37 \\
\hline 40.77 & 40.79 & 40.78 & 193 & 0.30 & 0.42 \\
\hline 40.95 & 40.95 & 40.95 & 165 & 0.30 & 0.42 \\
\hline 41.10 & 41.10 & 41.10 & 2,269 & 0.49 & 0.65 \\
\hline 41.25 & 41.26 & 41.26 & 2,239 & 0.49 & 0.56 \\
\hline 41.51 & 41.56 & 41.53 & 576 & 0.59 & 0.71 \\
\hline 41.64 & 41.71 & 41.67 & 1,577 & 0.58 & 0.73 \\
\hline 41.79 & 41.81 & 41.80 & 220 & 0.43 & 0.62 \\
\hline 41.90 & 41.94 & 41.92 & 572 & 0.52 & 0.62 \\
\hline 42.03 & 42.07 & 42.05 & 198 & 0.45 & 0.57 \\
\hline 42.12 & 42.15 & 42.14 & 1,145 & 0.47 & 0.60 \\
\hline 42.16 & 42.23 & 42.20 & 496 & 0.54 & 0.67 \\
\hline 42.35 & 42.40 & 42.38 & 545 & 0.47 & 0.60 \\
\hline 42.40 & 42.45 & 42.43 & 491 & 0.52 & 0.66 \\
\hline 42.55 & 42.58 & 42.57 & 322 & 0.47 & 0.60 \\
\hline 42.63 & 42.66 & 42.65 & 383 & 0.46 & 0.59 \\
\hline 42.78 & 42.78 & 42.78 & 557 & 0.52 & 0.65 \\
\hline 42.84 & 42.84 & 42.84 & 149 & 0.50 & 0.63 \\
\hline 42.93 & 42.93 & 42.93 & 361 & 0.41 & 0.53 \\
\hline 43.00 & 43.00 & 43.00 & 723 & 0.42 & 0.55 \\
\hline 45.53 & 45.55 & 45.54 & 729 & 0.55 & 0.68 \\
\hline 48.63 & 48.73 & 48.68 & 738 & 0.55 & 0.69 \\
\hline 51.54 & 51.56 & 51.55 & 339 & 0.53 & 0.66 \\
\hline 56.32 & 56.37 & 56.35 & 256 & 0.45 & 0.58 \\
\hline 63.64 & 63.69 & 63.67 & 697 & 0.58 & 0.71 \\
\hline 68.85 & 68.90 & 68.88 & 548 & 0.49 & 0.62 \\
\hline 77.20 & 77.30 & 77.25 & 33 & 0.43 & 0.56 \\
\hline 80.40 & 80.60 & 80.50 & 277 & 0.46 & 0.59 \\
\hline 91.03 & 91.08 & 91.06 & 29 & 0.42 & 0.54 \\
\hline 108.62 & 108.66 & 108.64 & 647 & 0.49 & 0.62 \\
\hline 112.60 & 112.68 & 112.64 & 735 & 0.49 & 0.62 \\
\hline
\end{tabular}


Table 1 IC value and illite peak intensity of all the measured samples from the entire borehole core (Continued)

\begin{tabular}{|c|c|c|c|c|c|}
\hline 113.29 & 113.39 & 113.34 & 166 & 0.38 & 0.51 \\
\hline 113.92 & 113.92 & 113.92 & 527 & 0.53 & 0.66 \\
\hline 114.25 & 114.28 & 114.27 & 1,639 & 0.62 & 0.75 \\
\hline 114.70 & 114.70 & 114.70 & 1,607 & 0.60 & 0.73 \\
\hline 124.45 & 124.49 & 124.47 & 954 & 0.51 & 0.64 \\
\hline 137.86 & 137.95 & 137.91 & 213 & 0.41 & 0.54 \\
\hline 141.07 & 141.13 & 141.10 & 520 & 0.48 & 0.61 \\
\hline 154.00 & 154.04 & 154.02 & 139 & 0.38 & 0.51 \\
\hline 164.72 & 164.83 & 164.78 & 700 & 0.44 & 0.57 \\
\hline 179.33 & 179.35 & 179.34 & 306 & 0.44 & 0.57 \\
\hline 188.75 & 188.77 & 188.76 & 214 & 0.45 & 0.58 \\
\hline 194.00 & 194.01 & 194.01 & 665 & 0.53 & 0.66 \\
\hline 207.15 & 207.15 & 207.15 & 172 & 0.41 & 0.54 \\
\hline 211.40 & 211.70 & 211.55 & 738 & 0.42 & 0.55 \\
\hline 220.20 & 220.20 & 220.20 & 377 & 0.40 & 0.53 \\
\hline 236.38 & 236.38 & 236.38 & 939 & 0.48 & 0.61 \\
\hline 242.30 & 242.32 & 242.31 & 373 & 0.42 & 0.55 \\
\hline 254.00 & 254.00 & 254.00 & 593 & 0.43 & 0.55 \\
\hline
\end{tabular}

$\mathrm{IC}_{\text {measured }}$ and IC IIC are the measured IC value and JIC-converted IC value, respectively.

We therefore excluded the IC values of the samples within these fault zones from the paleotemperature estimation.

We calculated the paleotemperatures using the following empirical conversion formula (Mukoyoshi et al. 2007):

$$
\mathrm{T}\left({ }^{\circ} \mathrm{C}\right)=353-206 \times \mathrm{IC}_{\mathrm{JIC}}
$$

The estimated paleotemperatures are $288^{\circ} \mathrm{C}$ to $299^{\circ} \mathrm{C}$ $\left(294^{\circ} \mathrm{C}\right.$ average with standard deviation of $\left.4.3^{\circ} \mathrm{C}\right)$ in the hanging wall and $198^{\circ} \mathrm{C}$ to $249^{\circ} \mathrm{C}\left(228^{\circ} \mathrm{C}\right.$ average with standard deviation of $12.5^{\circ} \mathrm{C}$ ) in the footwall, respectively. These temperatures are approximately $20^{\circ} \mathrm{C}$ to $30^{\circ} \mathrm{C}$ lower than the previously estimated values based on a vitrinite reflectance analysis (approximately $320^{\circ} \mathrm{C}$ and approximately $255^{\circ} \mathrm{C}$ for the hanging wall and footwall, respectively; Kondo et al. 2005); however, a large temperature difference between hanging wall and footwall is nonetheless exhibited.

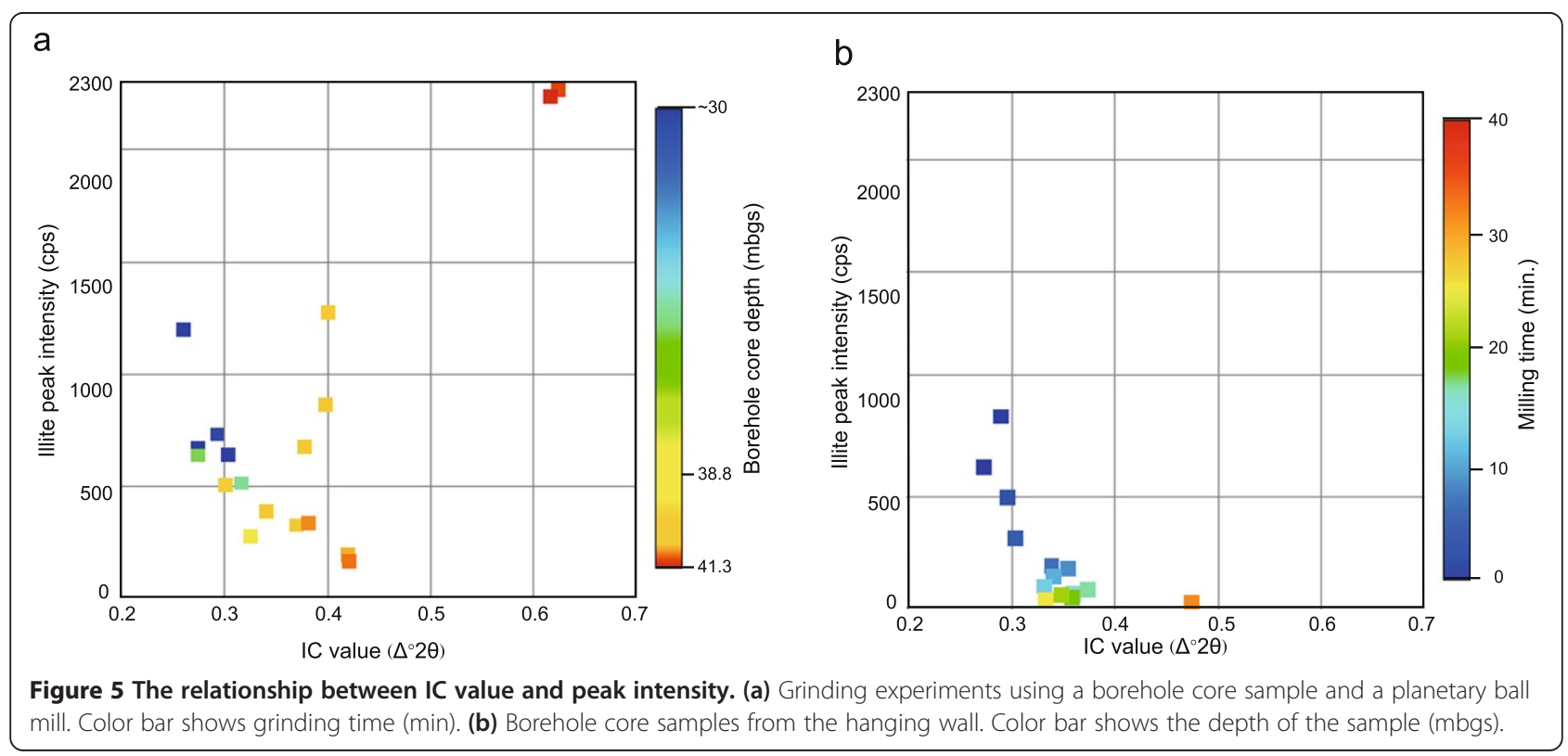


Table 2 Experimental results (IC values and intensity) using the borehole core samples (left) and sericite standard samples (right)

\begin{tabular}{|c|c|c|c|c|c|c|c|}
\hline \multicolumn{4}{|c|}{ Borehole core sample } & \multicolumn{4}{|l|}{ Sericite } \\
\hline Time (min) & $\begin{array}{l}\text { Illite peak } \\
\text { intensity (cps) }\end{array}$ & IC values $\left(\Delta^{\circ} \mathbf{2 \theta}\right)$ & $\begin{array}{l}\text { IC value calibrated } \\
\text { by JIC }\left(\Delta^{\circ} 2 \theta\right)\end{array}$ & Time (min) & $\begin{array}{l}\text { Illite peak } \\
\text { intensity (cps) }\end{array}$ & IC values $\left(\Delta^{\circ} \mathbf{2 \theta}\right)$ & $\begin{array}{l}\text { IC value calibrated } \\
\text { by JIC }\left(\Delta^{\circ} 2 \theta\right)\end{array}$ \\
\hline 0 & 629 & 0.15 & 0.27 & 0 & 5837 & 0.21 & 0.33 \\
\hline 1 & 853 & 0.17 & 0.28 & 1 & 5228 & 0.24 & 0.36 \\
\hline 2 & 491 & 0.17 & 0.29 & 2 & 4560 & 0.25 & 0.37 \\
\hline 4 & 314 & 0.18 & 0.30 & 4 & 3534 & 0.26 & 0.38 \\
\hline 6 & 190 & 0.21 & 0.33 & 6 & 5129 & 0.28 & 0.40 \\
\hline 8 & 179 & 0.23 & 0.35 & 8 & 3526 & 0.28 & 0.41 \\
\hline 10 & 139 & 0.21 & 0.33 & 10 & 3534 & 0.27 & 0.39 \\
\hline 12 & 99 & 0.21 & 0.32 & 12 & 2192 & 0.26 & 0.38 \\
\hline 14 & 67 & 0.23 & 0.35 & 14 & 1408 & 0.27 & 0.39 \\
\hline 16 & 82 & 0.25 & 0.37 & 16 & 1744 & 0.24 & 0.37 \\
\hline 18 & 53 & 0.23 & 0.35 & 18 & 1430 & 0.27 & 0.39 \\
\hline 20 & 60 & 0.22 & 0.34 & 20 & 861 & 0.24 & 0.36 \\
\hline 25 & 39 & 0.21 & 0.33 & & & & \\
\hline 30 & 25 & 0.34 & 0.47 & 30 & 1015 & 0.29 & 0.41 \\
\hline 40 & 28 & 0.01 & 0.12 & 40 & 683 & 0.27 & 0.39 \\
\hline 60 & 0 & 0.00 & 0.11 & 60 & 535 & 0.53 & 0.66 \\
\hline 90 & 0 & 0.00 & 0.11 & 90 & 7 & 0.82 & 0.96 \\
\hline
\end{tabular}

$\mathrm{IC}_{\text {measured }}$ and IC IIC are the measured IC value and JIC-converted IC value, respectively.

Negative anomalies of IC values (i.e., illite crystal growth under higher temperature conditions) were not detected along the fault core (Figure 4). Their absence suggests that neither the temperature rise caused by frictional heat and/ or hot hydrothermal fluid flow along the fault core nor its duration is enough to affect IC value.

Factors controlling illite crystallinity within fault zone

The IC values of the hanging wall damage zone below 38.8 mbgs (Figure 4b) increase systematically toward the fault core of the Nobeoka Thrust; in other words, the crystallinity of illite decreases toward the fault core. Similar IC behavior near a fault core was reported, for instance, from the Matapedia fault in Canada (Duba and Williams-Jones, 1983), the Sashiu fault in Southwest Japan (Yamakita et al. 1995), and the Akaishi Tectonic Line in central Japan (Tanaka et al. 1995). Tanaka et al. (1995) argued that IC values increase toward the fault because muscovite crystals are buckled, fractured, and comminuted into finer grain sizes or replaced by fine crystals via hydrothermal alteration and the recrystallization of micaceous clay minerals. Although Hara and Kimura (2000) pointed out that lithological differences, deformation, hydrothermal alteration, and weathering are the controlling factors for IC value, we first focused on the effect of deformation and fragmentation due to the faulting before moving on to examine the other effects such as hydrothermal alteration on the basis of bulk-rock mineralogy.

In our grinding experiments, IC value increased with grinding time, whereas illite peak intensity decreased with grinding time (Figure 5b, Table 2) regardless of whether natural (35.49 mbgs) or standard samples were used. The experimental results suggest that the poorly crystallized illite progressively increases as a result of comminution (Figure 6a,b). The IC values and peak intensities of the samples from 20 to 41 mbgs in the hanging wall exhibited a similar tendency to those from the grinding experiments. In the natural borehole samples of the hanging wall damage zone, IC value increases as it approaches the Nobeoka Thrust to approximately 0.30 $\Delta^{\circ} 2 \theta$, whereas illite peak intensity decreases toward the Nobeoka Thrust to approximately $170 \mathrm{cps}$, at depths 40.95 mbgs (the blue, green, yellow, and orange solid squares in Figure 5a; the original data are shown in Table 2), except for three points characterized by high illite peak intensities (approximately 680 to $1300 \mathrm{cps}$ ) instead of relatively large IC values ( 0.38 to $0.40 \Delta^{\circ} 2 \theta$ ). The similarity between the experimental (Figure 6a,b) and natural (Figure 6,d) samples suggests that the degree of comminution increases progressively toward the fault core of the Nobeoka Thrust. Deformational features of the core samples (Figure 2a,b) are also consistent with this tendency. 

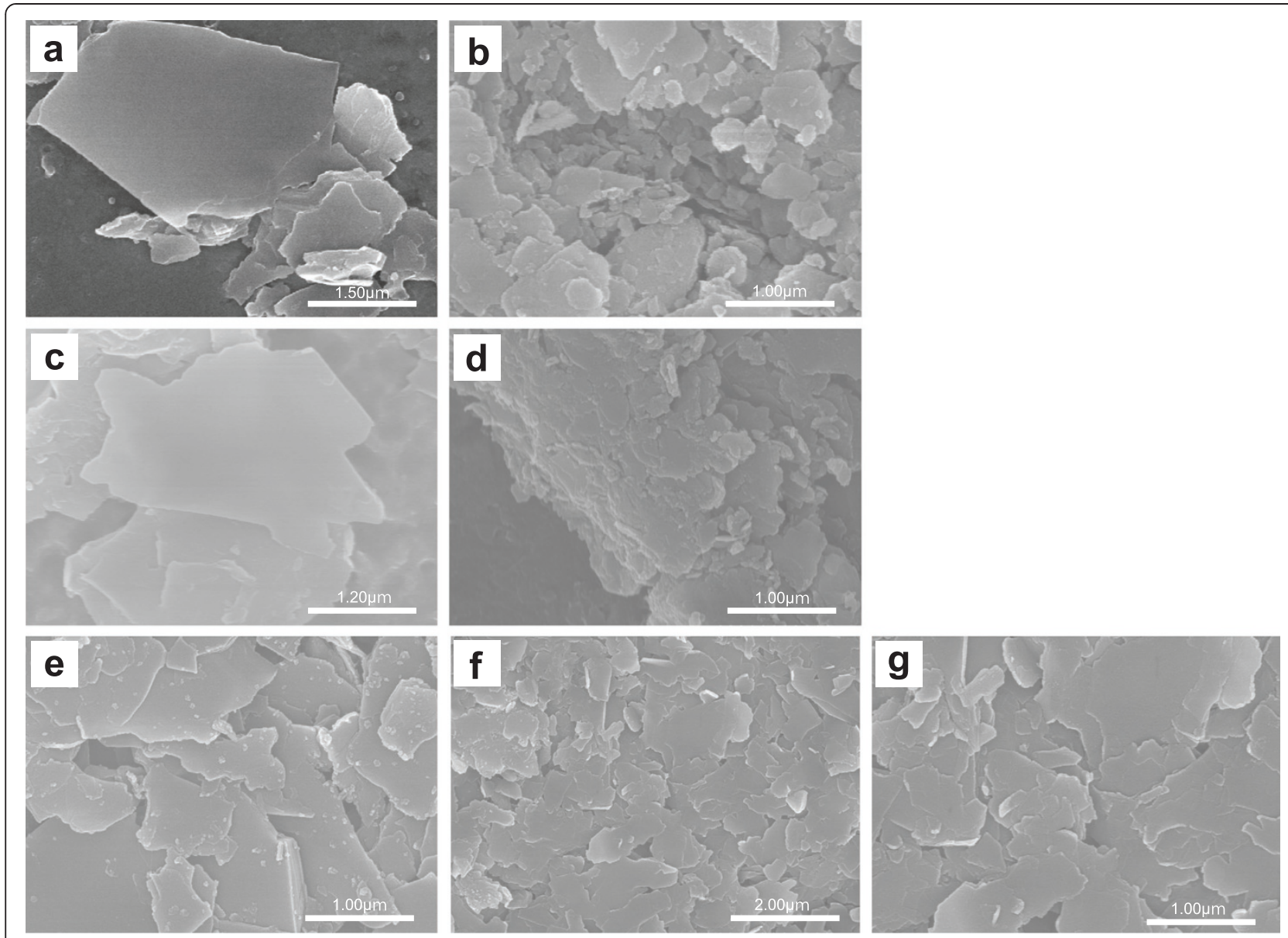

Figure 6 FE-SEM images of ground $(\mathbf{a}, \mathbf{b})$ and natural (c-g) clay mineral grain shapes. (a) Starting material of the experimental sample obtained from 35.49 mbgs. (b) The experimental products after $10 \mathrm{~min}$ of grinding. Grains are fragmented and comminuted. (c) Clays in phyllite having not experienced mechanical comminution, 3.11 mbgs. (d) Clays in mechanically comminuted phyllite, 39.41 mbgs in the damage zone. (e) Mechanically comminuted grains slightly coated with small authigenic illite showing the lateral growth step, 40.95 mbgs in the damage zone. (f) Comminuted grains completely coated with large crystals of authigenic illite, 41.26 mbgs just above the fault core. (g) The enlarged picture of 41.26 mbgs just above the fault core (Figure 6f).

However, an abrupt increase in both IC value and illite peak intensity was observed just above the fault core ( 41.10 to 41.26 mbgs; two red points in Figure 5a): the IC value is $0.62 \Delta^{\circ} 2 \theta$ and the peak intensities are approximately 2,239 to $2,269 \mathrm{cps}$. This trend is completely opposite to the tendency we observed in the grinding experiments and core samples above $40.95 \mathrm{mbgs}$, and it cannot be explained by comminution. The trend observed just above the fault core might be explained by an authigenic formation of small illite crystals (Figure 6f,g) caused by the circulation of hydrothermal fluid along the fault core, which is geologically recorded as mineral veins accumulated just above the fault core (Figure 2c).

In the upper portion of the fault core ( $41.34 \mathrm{mbgs})$, the bulk-rock mineralogy (Figure 3) showed that clay minerals and carbonates are markedly enriched and the plagioclase content becomes little or none. Such an unusual mineral assemblage is observed only at this depth, and plagioclase is abundant in all of the borehole cores except at this depth. Hemley and Jones (1964) demonstrated that albite transforms to fine-grained white mica as a result of alteration under the following water-saturated conditions:

$$
\begin{aligned}
& 3 \mathrm{NaAlSi}_{3} \mathrm{O}_{8}(\text { albite })+\mathrm{K}^{+}+2 \mathrm{H}^{+} \rightarrow \\
& \mathrm{KAl}_{3} \mathrm{Si}_{3} \mathrm{O}_{10}(\mathrm{OH})_{2}(\text { white mica })+6 \mathrm{SiO}_{2}+3 \mathrm{Na}^{+}
\end{aligned}
$$

Wintsch et al. (1995) demonstrated that the transformation of feldspar into phyllosilicate such as chlorite and mica results in the weakening of fault zones. Jefferies et al. 2006a,b also reported that plagioclase altered to sericite within the fault core of the Median Tectonic Line (MTL) in Japan. Hydrothermal alteration, which causes the breakdown of feldspar and the new formation of white mica, is a reasonable mechanism to explain the increase in the amount of illite in the fault core at around 41.34 mbgs. Interestingly, feldspar breakdown in fault core is opposite 
to some other thrusts in subduction setting. For example, plagioclase was newly formed by $>350^{\circ} \mathrm{C}$ water-rock interaction in the fault core of the Pasagshak Point Thrust in the Kodiak accretionary complex, Alaska (Yamaguchi et al. 2014), although both the Nobeoka Thrust and the Pasagshak Point Thrust were active at similar background temperatures of approximately $250^{\circ} \mathrm{C}$.

There are a couple of possibilities to explain the three exceptional points in Figure 5a, that is, the high illite peak intensities (approximately 680 to $1,300 \mathrm{cps}$ ) with relatively large IC values ( 0.38 to $\left.0.40 \Delta^{\circ} 2 \theta\right)$. One possibility is that high peak intensities resulted from extremely enriched clay minerals in the host rock. Another possibility is a transitional or beginning stage of hydrothermal alteration that produced large amounts of illite. Further mineralogical investigations are necessary to reconcile the origin of illite with the high peak intensities and IC values.

Based on the results of the study, we propose that the increase in IC values in the hanging wall damage zone of the Nobeoka Thrust is due to mechanical comminution, in light of our comparisons of borehole core samples (Figures 5a and 6c,d) and products of grinding experiments (Figures $5 \mathrm{~b}$ and $6 \mathrm{a}, \mathrm{b}$ ). Moreover, the abrupt increase in IC value accompanied by high illite peak intensity (Figure 5a) is explained by hydrothermal alteration that causes plagioclase breakdown and formation of white micas (Figure 6e,f,g). The IC values within fault zones have the highest potential utility for detecting the effects of comminution and alteration rather than for the estimation of paleotemperatures.

\section{Conclusions}

The following conclusions were drawn from this study:

1) The IC values of the borehole core across the Nobeoka Thrust show a remarkable difference between the hanging wall and the footwall. The maximum diagenetic temperatures of the hanging wall and the footwall are estimated to be $288^{\circ} \mathrm{C}$ to $299^{\circ} \mathrm{C}$ and $198^{\circ} \mathrm{C}$ to $249^{\circ} \mathrm{C}$, respectively. These values are approximately $20^{\circ} \mathrm{C}$ to $30^{\circ} \mathrm{C}$ lower than their previously reported paleotemperatures based on vitrinite reflectance (Kondo et al. 2005).

2) The fault core of the Nobeoka Thrust does not exhibit a significant IC value decrease.

3) In the hanging wall damage zone, IC value systematically increases as it approaches the Nobeoka Thrust, whereas illite peak intensity shows the opposite trend. These patterns were similarly observed in the results of the grinding experiments, which showed that IC value increases and illite peak intensity decreases with increased grinding time, thus suggesting that the degree of mechanical comminution is increased toward the fault core.

4) The abrupt increase in IC value accompanied by high illite peak intensity is explained by hydrothermal alteration including plagioclase breakdown and formation of white micas.

\section{Additional file}

Additional file 1: Table S1. Measured IC values of six JIC standards (left) compared with values reported by Hara and Kimura (2003) (right).

\section{Competing interests}

The authors declare that they have no competing interests.

\section{Authors' contributions}

RF made substantial contributions to the conception and design, analysis, and interpretation of data. KF, JK, MH, AY, and GK participated in design and coordination and helped to draft the manuscript. YohH, YosH, YK, and SS contributed and participated in the Nobeoka Thrust Drilling Project. All authors read and approved the final manuscript.

\section{Acknowledgements}

This work was supported by MEXT and JSPS KAKENHI (Grant nos. 21107005 and 23244099) and the Center for Advanced Marine Core Research, Kochi University (CMCR) Nationwide Joint Use System (12A007, 12B006). We express our heartfelt gratitude to Y. Mizuochi, K. Hase, T. Akashi, and the technicians from Sumiko Resources Exploration \& Development (SRED) for performing the coring during the Nobeoka Thrust Drilling Project. We express our deepest appreciation to T. Kanda of the Miyazaki University for the hospitality during our stay at the Nobeoka Marine Science Station. We are also grateful for the contributions of S. Hina and M. Eida regarding the observation of borehole core samples. We would like to express our gratitude to $\mathrm{H}$. Hara, who provided the JIC samples for IC calibration. An earlier version of the manuscript was improved by insightful comments and suggestions from two anonymous reviewers.

\section{Author details}

${ }^{1}$ Department of Earth and Planetary Science, Graduate School of Science, The University of Tokyo, 7-3-1 Hongo, Bunkyo-ku, Tokyo 113-0033, Japan. ${ }^{2}$ Faculty of Education, Tokyo Gakugei University, 4-1-1 Nukui-kitamachi, Koganei-shi, Tokyo 184-8501, Japan. ${ }^{3}$ Earth and Planetary System Science, Department of Natural History Sciences, Graduate School of Science, Hokkaido University, N10 W8, Sapporo 060-0810, Japan. ${ }^{4}$ Atmosphere and Ocean Research Institute, The University of Tokyo, 5-1-5, Kashiwanoha, Kashiwa-shi, Chiba 277-8564, Japan. ${ }^{5}$ Institute for Research on Earth Evolution, Japan Agency for Marine-Earth Science and Technology, 2-15 Natsushima-cho, Yokosuka, Kanagawa 237-0061, Japan. ${ }^{6}$ Department of Applied Science, Faculty of Science, Kochi University, 2-5-1 Akebono-cho, Kochi-shi, Kochi 780-8520, Japan. ${ }^{7}$ Department of Earth and Environmental Sciences, Graduate School of Science and Engineering, Kagoshima University, 1-21-35, Korimoto, Kagoshima 890-0065, Japan.

Received: 10 March 2014 Accepted: 29 August 2014 Published: 11 September 2014

\section{References}

Awan MA, Kimura K (1996) Thermal structure and uplift of the Cretaceous Shimanto Belt, Kii Peninsula, Southwestern Japan: an illite crystallinity and illite $b_{0}$ lattice spacing study. The Island Arc 5:69-88

Duba D, Williams-Jones AE (1983) The application of illite crystallinity, organic matter reflectance, and isotopic techniques to mineral exploration: a case study in Southwestern Gaspe, Quebec. Econ Geol 78:1350-1363

Hamahashi M, Saito S, Kimura G, Yamaguchi A, Fukuchi R, Kameda J, Hamada Y, Kitamura Y, Fujimoto K, Hashimoto Y, Hina S, Eida M (2013) Contrasts in physical properties between the hanging wall and footwall of an exhumed seismogenic megasplay fault in a subduction zone-an example from the 
Nobeoka Thrust Drilling Project. Geochemistry, Geophysics, Geosystems 14:5354-5370

Hara H, Kimura K (2000) Estimation of errors in measurement of illite crystallinity: the limits and problems of application to accretionary complexes.

J Geol Soc Japan 106(4):264-279 (in Japanese with English abstract)

Hara H, Kimura K (2003) New proposal of standard specimens for illite crystallinity measurement: its usefulness as paleo-geothermal indicator. Bull Geological Survey Japan 54:239-50 (in Japanese with English abstract)

Hara H, Kimura K (2008) Metamorphic and cooling history of the Shimanto accretionary complex, Kyushu, Southwest Japan: Implications for the timing of out-of-sequence thrusting. Island Arc 17:546-559

Hemley JJ, Jones WR (1964) Chemical aspects of hydrothermal alteration with emphasis on hydrogen metasomatism. Econ Geol 59:538-569

Hyndman R, Wang K (1993) Thermal constraints on the zone of major thrust earthquake failure: the Cascadia subduction zone.

J Geophys Res 98:2039-2060

Hyndman R, Wang K (1995) The rupture zone of Cascadia great earthquakes from current deformation and the thermal regime. J Geophys Res All Series 100:22-22

Hyndman RD, Yamano M, Oleskevich DA (1997) The seismogenic zone of subduction thrust faults. Island Arc 6(3):244-260

Jefferies SP, Holdsworth RE, Wibberley CAJ, Shimamoto T, Spiers CJ, Niemeijer AJ, Lloyd GE (2006a) The nature and importance of phyllonite development in crustal-scale fault cores: an example from the Median Tectonic Line, Japan. J Struct Geol 28:220-235

Jefferies SP, Holdsworth RE, Shimamoto T, Takagi H, Lloyd GE, Spiers CJ (2006b) Origin and mechanical significance of foliated cataclastic rocks in the cores of crustal-scale faults: examples from the Median Tectonic Line, Japan. J Geophys Res 111:B12303

Kimura K (1998) Out-of-sequence thrust of an accretionary complex. Mem Geol Soc Japan 50:131-146 (in Japanese with English abstract)

Kimura K, Iwaya T, Mimura K, Sato Y, Geology of the Osuzuyama District (1991) Quadrangle Series 1:50,000, Geological Survey of Japan, Tsukuba (in Japanese with English abstract)., pp 119-124

Kimura G, Hamahashi M, Okamoto S, Yamaguchi A, Kameda J, Raimbourg H, Hamada Y, Yamaguchi H, Shibata T (2013) Hanging wall deformation of a seismogenic megasplay fault in an accretionary prism: the Nobeoka Thrust in southwest Japan. J Struct Geol, doi.org/10.1016

Kondo H, Kimura G, Masago H, Ohmori-lkehara K, Kitamura Y, Ikesawa E, Sakaguchi A, Yamaguchi A, Okamoto S (2005) Deformation and fluid flow of a major outof-sequence thrust located at seismogenic depth in an accretionary complex: Nobeoka Thrust in the Shimanto Belt, Kyushu, Japan. Tectonics 24:TC6008, 16pp

Kübler B (1968) Evaluation quantitative du metamorphism par la cristallinite de I'lllite. Bull Centre de Recherches dep Pau-SNPA 2:385-97

Miyawaki R, Sano T, Ohashi F, Suzuki M, Kogure T, Okumura T, Kameda J, Umezome T, Sato T, Chino D, Hiroyama K, Yamada H, Tamura K, Morimoto K, Uehara S, Yatta T (2010) Some reference data for the JCSS clay specimens. J Clay Sci Soc Japan 48(4):158-198

Mukoyoshi H, Hara H, Omori K (2007) Quantitative estimation of temperature conditions for illite crystallinity: comparison to vitrinite reflectance from the Chichibu and Shimanto accretionary complexes, eastern Kyushu, Southwest Japan. Bull Geological Survey Japan 58:23-31 (in Japanese with English abstract)

Murata A (1998) Duplexes and low-angle nappe structures of the Shimanto Terrane, southwest Japan. Mem Geol Soc Japan 50:147-158 (in Japanese with English abstract)

Nishi H (1988) Structural analysis of part of the Shimanto accretionary complex, Kyushu, Japan, based on planktonic foraminiferal zonation. Modern Geology 12:47-69

Okamoto S, Kimura G, Takizawa S, Yamaguchi H (2006) Earthquake fault rock indicating a coupled lubrication mechanism. e-Earth 1:23-28

Okumura K, Teraoka Y, Sugiyama Y, Geology of the Kamae District (1985) Quadrangle Series 1: 50,000, Geological Survey of Japan, Tsukuba (in Japanese with English abstract)

Oleskevich DA, Hyndman RD, Wang K (1999) The updip and downdip limits to great subduction earthquakes: thermal and structural models of Cascadia, south Alaska, SW Japan and Chile. J Geophys Res 104:14,965-14,991

Raimbourg H, Shibata T, Yamaquchi A, Yamaguchi H, Kimura G (2009) Horizontal shortening versus vertical loading in accretionary prisms. Geochem Geophys Geosyst 10:Q04007

Saito M, Kimura K, Naito K, Sakai A, Geology of the Shiibamura District (1996) Quadrangle Series 1: 50,000, Geological Survey of Japan, Tsukuba (in Japanese with English abstract)
Tanaka H, Uehara N, Itaya T (1995) Timing of cataclastic deformation of the Akaishi Tectonic Line, central Japan. Contrib Mineral Petrol 120:150-158

Underwood MB, Laughland MM, Kang SM (1993) A comparison among organic and inorganic indicators of diagenesis and low-temperature metamorphism Tertiary Shimanto Belt, Shikoku Japan. Geol Soc Am Special Paper 273:45-61

Wintsch RP, Christoffersen R, Kronenberg AK (1995) Fluid-rock reaction weakening of fault zones. J Geophys Res 100:13021-13032

Yamaguchi A, Cox SF, Kimura G, Okamoto S (2011) Dynamic changes in fluid redox state associated with episodic fault rupture along a megasplay fault in a subduction zone. Earth Planet Sci Lett 302:369-377

Yamaguchi A, Ishikawa T, Kato Y, Nozaki T, Meneghin F, Rowe CD, Moore JC, Tsutsumi A, Kimura G (2014) Fluid-rock interaction recorded in black fault rocks in the Kodiak accretionary complex, Alaska. Earth Planets Space 66:58

Yamakita S, Ito T, Tanaka H, Watanabe H (1995) Early Oligocene top-to-the-west motion along the Sashu fault, a low-angle oblique thrust of the paleoMedian Tectonic Line, east Kyushu, Japan. J Geol Soc Japan 101(12):978-989 (in Japanese with English abstract)

doi:10.1186/1880-5981-66-116

Cite this article as: Fukuchi et al:: Changes in illite crystallinity within an ancient tectonic boundary thrust caused by thermal, mechanical, and hydrothermal effects: an example from the Nobeoka Thrust, southwest Japan. Earth, Planets and Space 2014 66:116.

\section{Submit your manuscript to a SpringerOpen ${ }^{\odot}$ journal and benefit from:}

- Convenient online submission

Rigorous peer review

- Immediate publication on acceptance

- Open access: articles freely available online

- High visibility within the field

- Retaining the copyright to your article

Submit your next manuscript at $\gg$ springeropen.com 